\title{
Peran stres akademik dan hardiness terhadap kecenderungan gangguan psikofisiologis pada mahasiswa kedokteran tahun pertama
}

\author{
I Made Riantama Adi Saputra dan Luh Made Karisma Sukmayanti Suarya \\ Program Studi Sarjana Psikologi, Fakultas Kedokteran, Universitas Udayana \\ karismasukmayanti@unud.ac.id
}

\begin{abstract}
Abstrak
Gangguan psikofisiologis merupakan gangguan fisik yang disebabkan oleh faktor-faktor psikologis terutama stres. Gangguan psikofisiologis memfokuskan perhatian pada hubungan kausal satu arah pada interaksi antara psike dan soma, atau dampak dari faktor psikologis secara negatif terhadap kondisi medis secara umum. Bagi sebagian individu, pendidikan kedokteran dipersepsikan sebagai keadaan yang penuh dengan stres. Adanya stres akademik pada mahasiswa kedokteran, khususnya mahasiswa kedokteran tahun pertama memiliki konsekuensi yang merugikan terhadap kondisi kesehatan, seperti kecenderungan gangguan psikofisiologis. Hardiness merupakan sekumpulan trait dari karakteristik kepribadian yang menjadi sumber perlawanan ketika individu berhadapan dengan peristiwa yang penuh dengan stres. Adanya hardiness pada mahasiswa kedokteran tahun pertama akan membantu untuk mengatasi stres akademik secara efektif sehingga tidak mengarah pada kecenderungan gangguan psikofisiologis. Penelitian ini merupakan penelitian kuantitatif untuk mengetahui peran stres akademik dan hardiness terhadap kecenderungan gangguan psikofisiologis pada mahasiswa kedokteran tahun pertama. Pengambilan sampel dilakukan dengan teknik simple random sampling. Sebanyak 158 mahasiswa dari Program Studi Pendidikan Dokter Fakultas Kedokteran (FK) Universitas Udayana dan Fakultas Kedokteran dan Ilmu Kesehatan (FKIK) Universitas Warmadewa digunakan sebagai subjek dalam penelitian ini. Alat ukur yang digunakan adalah Skala Somatic Symptom Scale-8, Skala Gangguan Psikofisiologis, Skala Stres Akademik, dan Skala Hardiness. Hasil uji Moderated Regression Analysis (MRA) menunjukkan nilai koefisien parameter individual stres akademik sebesar 0,727 dengan signifikansi $0,028(p<0,05)$, yang berarti stres akademik berperan seacara signifikan terhadap kecenderungan gangguan psikofisiologis, selanjutnya nilai koefisien parameter individual moderasi Hardiness sebesar -0,003 dengan signifikansi 0,348 ( $>0,05$ ), yang berarti Hardiness tidak berperan secara signifikan dalam memperkuat ataupun memperlemah hubungan antara stres akademik terhadap kecenderungan gangguan psikofisiologis.
\end{abstract}

Kata Kunci: Stres Akademik, Hardiness, Kecenderungan Gangguan Psikofisiologis Mahasiswa Kedokteran Tahun Pertama

\begin{abstract}
Psychophysiological disorder is physical disorders which caused by psychological factors especially stress. Psychophysiological disorder focus attention on one way causal relationships on the interactions between psyche and soma, or effects of psychological factors negatively on general medical conditions. For some individuals, medical education is perceived as a stressful condition. The existence of academic stress in first-year medical students has adverse consequences on their health, such as psychophysiological disorder tendencies. Hardiness is constellation of personality characteristics that becomes the source of resistance when the individual faced with a stressful situation. The existence of hardiness in first-year medical students will help to resolve academic stress effectively that will not lead to the psychophysiological disorders tendencies. This research is a quantitative study to determine the role of academic stress and hardiness on tendency of psychophysiological disorder at first-year medical students. Sampling is done by simple random sampling technique. A total of 158 students from Program Studi Pendidikan Dokter Fakultas Kedokteran (FK) Universitas Udayana and Fakultas Kedokteran dan Ilmu Kesehatan (FKIK) Universitas Warmadewa were used as subjects in this study. Measuring tools which used of this study are Somatic Symptom Scale-8, Psychophysiological Disorder Scale, Academic Stress Scale, and Hardiness Scale. The Moderated Regression Analysis (MRA) test results showed value of individual parameters coefficient of academic stress equal to 0.727 with significance value of $0.028(\mathrm{p}<0.05)$, which mean that academic stress has a significant role to psychophysiological disorder, then value of individual parameter coefficient of moderate hardiness equal to -0.003 with significance value of $0.348(\mathrm{p}<0.05)$ which mean that hardiness has not have a significant role in strengthen or weaken relationship between academic stress on the psychophysiological disorders tendencies.
\end{abstract}

Keywords: Academic Stress, Hardiness, Psychophysiological Disorder Tendencies, First Year Medical Students 


\section{STRES AKADEMIK DAN HARDINESS TERHADAP KECENDERUNGAN GANGGUAN PSIKOFISIOLOGIS}

\section{LATAR BELAKANG}

Faktor psikologis dapat memengaruhi kesehatan fisik, baik secara langung dengan menghasilkan perubahan-perubahan pada hormon dan/atau detak jantung atau secara tidak langsung dengan mengubah perilaku yang memengaruhi kesehatan individu. Faktor psikologis juga berperan dalam perkembangan berbagai penyakit seperti kaitannya dalam memulai, pemberatan, atau predisposisi terhadap penyakit (Kaplan, Sadock, \& Grebb, 2010). Keluhan-keluhan ringan seperti sakit kepala, perut mulas, mual, hingga jantung berdebar-debar seringkali hanya dipicu oleh kondisi ketika individu merasa stres. Diperkirakan, 20\% hingga 30\% pasien yang datang ke dokter umum dengan keluhan ringan hanya mengalami stres (Pramudiarja, 2011). Sejalan dengan hal tersebut, penelitian lainnya melaporkan bahwa $20 \%$ dari pasien yang datang ke dokter pelayanan primer mengalami gejala fisik yang penyebabnya murni bersumber dari faktor psikologis (Lickerman, 2010).

Ketika individu mengalami stres yang berkepanjangan maka terjadi peningkatan produksi asam lambung, sehingga menyebabkan ulcer atau lubang pada dinding lambung. Ketika individu terpapar oleh ketakutan yang hebat, maka detak jantung menjadi sangat cepat dan terdapat kelelahan yang ekstrem akibat dari reaksi astenik atau berkurangnya kekuatan pada tubuh. Detak jantung yang cepat dan reaksi astenik yang muncul merupakan gejala fisik yang disebabkan oleh konflikkonflik emosional yang bersifat psikologis (Semiun, 2006). Menurut Sarafino dan Smith (2010), kondisi demikian disebut sebagai gangguan psikofisiologis, yang mengacu pada gejala fisik atau penyakit yang diakibatkan oleh interaksi proses psikososial dan fisiologis.

Gangguan psikofisiologis merupakan gangguan fisik dengan basis atau komponen psikologis yang kuat (Sue, Sue, Sue, \& Sue, 2016). Gangguan psikofisiologis berbeda dengan apa yang disebut sebagai gangguan somatoform. Gangguan somatoform ditandai oleh adanya faktor psikologis dan gejala fisik, namun tidak terdapat kondisi medis umum yang dapat menjelaskan gejala fisik secara keseluruhan (American Psychiatric Association [APA], 2000). Sedangkan gangguan psikofisiologis mencakup adanya kerusakan tubuh, sehingga gangguan fisik yang muncul tidak hanya sebatas imajiner dan rekaan, tetapi benar-benar nyata berupa sakit fisik aktual yang dialami oleh individu (Davison, Neale, \& Kringg, 2014; Kaplan et al., 2010).

Sejak 1980, Diagnostic and Statistical Manual of Mental Disorders III, III-R, dan IV (DSM-III, DSM-III-R, dan DSMIV) menggunakan faktor psikologis yang memengaruhi kondisi fisik sebagai kategori diagnostik yang tepat untuk mengklasifikasikan gangguan psikofisiologis. Pada Diagnostic and Statistical Manual of Mental Disorders IV-TR, gangguan psikofisiologis didefinisikan sebagai kondisi medis apapun yang dipengaruhi secara negatif oleh faktor psikologis seperti stres, perilaku, atau mood (Van Hasselt \& Hersen, 1994). Gangguan psikofisiologis dicantumkan dalam faktor psikologis yang memengaruhi kondisi medis, dan diagnosisnya dikodekan dalam bagian luas yang mencakup berbagai kondisi lain yang dapat menjadi perhatian klinis (Davison et al., 2014).
Salah satu faktor psikologis yang ditengarai menjadi penyebab terjadinya gangguan psikofisiologis adalah stres (Davison et al., 2014). Stres merupakan keadaan ketika interaksi dan penyesuaian mengarahkan individu merasa adanya kesenjangan antara tuntutan fisik atau psikologis dari suatu situasi dengan sumber daya biologis, psikologis, atau sosial yang dimilikinya (Lavallo; Lazarrus \& Folkman, dikutip dalam Sarafino \& Smith, 2010). Stres menyebabkan perubahan pada tubuh individu yang mungkin memiliki konsekuensi jangka pendek dan jangka panjang untuk kesehatan (Taylor, 2012). Ketika individu dalam keadaan stres, respon fisiologis terhadap stresor dapat menyebabkan peningkatan rangsangan, seperti meningkatnya denyut jantung, tekanan darah, tegangan otot, atau produksi asam lambung. Apabila peningkatan rangsangan berlangsung dalam jangka waktu yang lama, maka akan menimbulkan gangguangangguan fisik, seperti serangan jantung, hipertensi, sakit kepala, atau ulcer (Semiun, 2006).

Sebagai kondisi lingkungan yang dapat memicu psikopatologi, stres tidak dapat dipisahkan dari setiap aspek kehidupan individu (Davison et al., 2014). Stres dapat dialami oleh siapapun dan memiliki implikasi negatif apabila berakumulasi dalam kehidupan tanpa solusi yang tepat. Mahasiswa dalam kegiatannya juga tidak terlepas dari stres. Stresor pada mahasiswa dapat bersumber dari kehidupan akademiknya, terutama dari tuntutan eksternal dan internal (Heiman \& Kariv, 2005). Tuntutan eksternal dapat bersumber dari tugastugas kuliah, beban pelajaran, tuntutan orangtua agar mahasiswa berhasil secara akademik, dan penyesuaian sosial di lingkungan kampus (Heiman \& Kariv, 2005). Selain itu, tuntutan eksternal juga mencakup kompetensi pendidikan dan kompleksitas materi perkuliahan yang meningkat seiring berjalannya periode perkuliahan. Sedangkan tuntutan internal dapat bersumber dari kemampuan mahasiswa dalam mengikuti kegiatan akademik (Heiman \& Kariv, 2005).

Stres pada mahasiswa kedokteran sangat tinggi apabila dibandingkan dengan program studi lain di sektor non-medis (Navas, 2012). Stresor yang dianggap paling relevan adalah keharusan bagi mahasiswa kedokteran untuk mempelajari sejumlah besar materi perkuliahan dalam periode yang singkat sebelum akhirnya menjalani ujian dan dievaluasi (Heinen, Bullinger, \& Kocalevent, 2017). Banyaknya materi perkuliahan menciptakan stres karena ketidakmampuan untuk menangani semua informasi sekaligus dan kemungkinan untuk berhasil selama periode ujian menjadi sulit (Heinen et al., 2017).

Berdasarkan penelitian yang dilakukan oleh Maulana, Soleha, Saftarina, dan Siagian (2014) didapat bahwa tingkat stres pada mahasiswa kedokteran tahun pertama lebih tinggi dibandingkan dengan tingkat stres pada mahasiswa tahun kedua. Kemudian, penelitian yang dilakukan oleh Augesti (2015) menemukan bahwa stres pada mahasiswa kedokteran tingkat awal lebih tinggi dibandingan tingkat stres pada mahasiswa tingkat akhir. Hal ini menunjukkan bahwa mahasiswa kedokteran tahun pertama lebih stres dibandingkan dengan tahun-tahun lainnya dan menurun seiring tahun studi berlangsung (Abdulghani, AlKanhal, Mahmoud, Ponnamperuma, \& Alfaris, 2011). 
Mahasiswa kedokteran tahun pertama mengalami masa transisi kehidupan dari sekolah menengah atas menuju perguruan tinggi. Sebagaimana yang dikemukakan oleh Santrock (2007), masa transisi yang dialami oleh mahasiswa tahun pertama lebih kompleks dibandingkan masa transisi sekolah sebelumnya karena seringkali mengakibatkan perubahan dan terjadinya stres. Dampak dari adanya stres yang tinggi pada mahasiswa kedokteran memiliki konsekuensi merugikan dalam prestasi akademik, kompetensi, profesionalitas, dan kesehatan (Sutjiato, Kandou, \& Tucunan, 2015). Pernyataan ini sesuai dengan penelitian yang dilakukan oleh Murberg dan Bru (2007), yang mendapat hasil bahwa stres akademik yang dialami oleh peserta didik dapat meningkatkan risiko terpapar keluhan kesehatan berupa sakit kepala, sakit punggung bagian bawah dan nyeri leher dan/atau bahu, migrain, dan perasaan tegang. Dengan demikian, stres yang tinggi pada mahasiswa kedokteran tahun pertama memiliki konsekuensi merugikan pada kondisi kesehatan, terutama meningkatkan risiko kecenderungan gangguan psikofisiologis.

Pada dasarnya, individu memiliki kemampuan untuk dapat mengelola stres akibat dari situasi menekan yang dirasakannya, atau setidaknya mereduksi apa yang dirasakan dan meminimalisir dampak negatif yang dialami. Tidak semua individu memandang suatu kejadian yang sama sebagai kejadian yang membuat stres. Perbedaan trait dan karakteristik kepribadian memengaruhi bagaimana reaksi individu terhadap stres yang dialami. Bahkan, diantara individu yang menilai suatu situasi sebagai penuh stres, efek stres dapat bervariasi tergantung pada bagaimana individu menghadapi situasi tersebut (Davison et al., 2014).

Berbagai macam kepribadian individu telah banyak dipertimbangkan sebagai suatu trait dan karakteristik yang dapat mengurangi dampak stres secara fisik maupun psikologis, salah satunya adalah hardiness. Hardiness merupakan sekumpulan trait dari karakteristik kepribadian yang menjadi sumber perlawanan di saat individu menemui suatu peristiwa yang penuh dengan stres dan melindungi individu dari pengaruh negatif stres (Kobasa, Maddi, \& Khan, 1982). Hardiness mempertahankan dan meningkatkan kesehatan dan kinerja individu dibawah keadaan stres. Adanya hardiness pada individu sejatinya mengubah keadaan stres dari yang awalnya berpotensi sebagai ancaman menjadi kesempatan untuk bertumbuh (Maddi, 2013).

Hardiness merupakan suatu trait kepribadian yang dicirikan oleh perasaan komitmen daripada keterasingan, kendali daripada ketidakberdayaan, dan memersepsikan masalah sebagai tantangan daripada ancaman (Maddi, dikutip dalam King, 2014). Terdapat tiga trait kepribadian penyusun hardiness yang mencakup tantangan, komitmen dan kendali (Kobasa et al., 1982). Menurut Maddi (2013), individu yang memiliki trait tantangan dalam dirinya akan menerima bahwa hidup sejatinya tidak terlepas dari stres dan memandang perubahan yang penuh dengan stres sebagai kesempatan untuk bertumbuh. Individu yang memiliki trait tantangan akan memiliki pemikiran bahwa dirinya dapat belajar dari kegagalan sebagaimana belajar melalui keberhasilan. Trait komitmen pada individu melibatkan keyakinan bahwa dalam keadaan buruk sekalipun, bahwa penting bagi individu untuk tetap terlibat dengan apapun situasi yang terjadi, daripada larut dalam keterpisahan dan keterasingan. Sedangkan trait kendali mengarahkan individu pada keyakinan bahwa dalam keadaan buruk sekalipun, individu tetap perlu untuk mencoba mengubah keadaan stres dari yang awalnya berpotensi sebagai ancaman menjadi suatu kesempatan untuk bertumbuh. Lebih lanjut, individu yang memiliki trait kendali dalam dirinya akan merasa membuang-buang waktu apabila membiarkan dirinya larut dalam ketidakberdayaan dan menjadi pasif.

Secara konseptual, ketiga trait kepribadian penyusun hardiness harus kuat, agar dapat menyediakan individu keberanian dan motivasi untuk bekerja keras mengubah keadaan stres menjadi sebuah kesempatan untuk bertumbuh. Individu yang secara bersamaan kuat dalam komitmen, tantangan, dan kendali cenderung melihat hidup sebagai fenomena yang terus berubah dan memancing individu untuk belajar dan berubah, berpikir bahwa melalui proses perkembangan mereka dapat bekerja pada perubahan dengan mengubahnya menjadi pengalamaan pemenuhan, serta berbagi atas usaha dan pembelajaran yang dilakukan dengan cara yang suportif kepada orang terdekat dan instansi di kehidupan individu (Maddi, 2013).

Hardiness memiliki efek penyangga atau berfungsi sebagai moderator dari pengaruh stres yang membahayakan terhadap kinerja dan kesehatan individu, yaitu individu dengan hardiness tinggi lebih mampu untuk menahan dampak negatif dari stres kehidupan, sehingga memiliki kemungkinan lebih kecil untuk terserang penyakit dibandingkan individu dengan hardiness rendah (Kobasa et al., 1982). Pernyataan yang dikemukakan oleh Kobasa et al. (1982) juga sejalan dengan penelitian yang dilakukan oleh Chincolikar dan Kulkarini (2017) yang mendapat hasil bahwa individu dengan hardiness tinggi cenderung mengalami tingkat stres yang lebih rendah. Ketahanan terhadap penyakit pada individu dengan hardiness tinggi merupakan hasil dari persepsi terhadap perubahan hidup yang dipandang tidak terlalu stres atau individu memiliki lebih banyak sumber daya untuk mengatasi perubahan hidup (Kobasa, 1979; Kobasa et al., 1982). Individu dengan hardiness tinggi akan tetap mengharapkan hasil yang positif meskipun situasi yang dihadapi cukup berat, sehingga semakin tinggi hardiness pada individu maka semakin baik pula status kesehatan mental individu (Nurtjahjanti \& Ratnaningsih, 2011; Shriatnia, Mirdoraghi, Pakmehr, \& Iravani, 2013). Adanya hardiness pada mahasiswa kedokteran tahun pertama akan memunculkan konsistensi perilaku dari waktu ke waktu dan stabilitas perilaku dalam berbagai situasi, berupa tidak menyerah di bawah tekanan akademik, memandang stres akademik sebagai kesempatan untuk bertumbuh, dan tidak membiarkan diri tenggelam dalam ketidakberdayaan salama masa studi. Adanya hardiness pada mahasiswa kedoketeran tahun pertama akan menjadi modal untuk mengatasi stres akademik yang dialami selama masa studi secara efektif sehingga tidak mengarah pada kecenderungan gangguan psikofisiologis. 
Berdasarkan pemaparan di atas maka dapat dikatakan bahwa hardiness merupakan sekumpulan trait dari karakteristik kepribadian yang penting untuk dimiliki oleh individu, termasuk mahasiswa kedokteran tahun pertama terkait perannya dalam menahan dampak negatif stres akademik yang mengarah pada kecenderungan gangguan psikofisiologis. Penelitian ini diharapkan dapat memberikan manfaat secara teoretis dalam bidang ilmu psikologi klinis, psikologi kesehatan, dan psikologi pendidikan. Penelitian ini diharapkan mampu memberikan manfaat praktis berupa informasi tambahan bagi mahasiswa kedokteran tahun pertama terkait konsekuensi yang merugikan dari stres akademik terhadap kondisi kesehatan, terutama kecenderungan gangguan psikofisiologis. Penelitian ini diharapkan menjadi acuan bagi institusi pendidikan kedokteran agar menumbuhkan trait kepribadian penyusun hardiness yaitu komitmen, kendali, dan tantangan pada mahasiswa kedokteran tahun pertama melalui pemberian informasi mengenai peran hardiness dalam kehidupan akademik sehingga dapat mengantisipasi konsekuensi merugikan dari stres akademik terhadap kondisi kesehatan, terutama kecenderungan gangguan psikofisiologis.

\section{METODE PENELITIAN}

\section{Variabel dan Definisi Operasional}

Variabel bebas dalam penelitian ini adalah stres akademik, variabel tergantung dalam penelitian ini adalah gangguan psikofisiologis, serta variabel moderator dalam penelitian ini adalah hardiness. Adapun definisi operasional dari masingmasing variabel dalam penelitian ini adalah sebagai berikut

Stres Akademik

Stres yang disebabkan oleh lingkungan akademik lebih dikenal dengan istilah stres akademik. Stres akademik merupakan reaksi yang muncul pada peserta didik sebagai hasil kombinasi dari tuntutan akademik yang melebihi sumber daya yang tersedia dalam menghadapi tuntutan akademik. Stres akademik diukur dengan Skala Stres Akademik yang mengacu pada reaksi terhadap stres akademik, yaitu pemikiran, perilaku, reaksi tubuh, dan perasaan. Semakin tinggi skor total yang diperoleh, maka semakin tinggi pula stres akademik pada subjek, sebaliknya, semakin rendah skor total yang diperoleh, maka semakin rendah pula stres akademik pada subjek.

\section{Gangguan psikofisiologis}

Gangguan psikofisiologis merupakan gangguan fisik yang disebabkan oleh faktor-faktor psikologis terutama stres. Gangguan psikofisiologis memfokuskan perhatian pada hubungan kausal satu arah pada interaksi antara psike dan soma, atau dampak dari faktor psikologis secara negatif terhadap kondisi medis secara umum. Kondisi medis secara umum diukur dengan Somatic Symptom Scale - 8 (SSS - 8) yang mencakup masalah perut dan usus, sakit di punggung, sakit di lengan, kaki, atau persendian, sakit kepala, nyeri dada, pusing, merasa lelah, dan kesulitan tidur. Selanjutnya, faktor psikologis diukur dengan Skala Gangguan Psikofisiologis yang mengacu pada pengaruh negatif faktor psikologis terhadap kondisi medis secara umum, yaitu memengaruhi perjalanan kondisi medis secara umum, menghambat penanganan kondisi medis secara umum, memberikan risiko kesehatan, dan respon fisiologis terkait stres mencetuskan atau memperparah gejala kondisi medis secara umum. Semakin tinggi skor total yang diperoleh, maka semakin tinggi pula kecenderungan gangguan psikofisiologis pada subjek, sebaliknya, semakin rendah skor total yang diperoleh, maka semakin rendah pula kecenderungan gangguan psikofisiologis pada subjek.

Hardiness

$\overline{\text { Hardiness }}$ merupakan konstelasi atau sekumpulan trait dari karakteristik kepribadian berupa perasaan komitmen, respon positif terhadap tantangan, dan perasaaan kendali internal yang membantu individu untuk mengatasi stres secara efektif dan mengurangi dampak negatif dari stres. Hardiness diukur dengan Skala Hardiness yang mengacu pada trait kepribadian yang menyusun hardiness, yaitu komitmen, tantangan, dan kendali serta ciri-ciri individu dengan hardiness. Semakin tinggi skor total yang diperoleh, maka semakin tinggi pula hardiness pada subjek, sebaliknya, semakin rendah skor total yang diperoleh, maka semakin rendah pula hardiness pada subjek.

\section{Responden}

Populasi dalam penelitian ini adalah mahasiswa kedokteran tahun pertama yang sedang mengikuti pendidikan kedokteran di Kota Denpasar. Terdapat dua institusi pendidikan yang menyediakan pendidikan kedokteran tahap akademik atau sarjana kedokteran di Kota Denpasar, yaitu Fakultas Kedokteran Universitas Udayana dan Fakultas Kedokteran dan Ilmu Kesehatan Universitas Warmadewa (Konsil Kedokteran Indonesia [KKI], 2012). Ukuran populasi dalam penelitian ini sebesar 254 mahasiswa dengan rinician 92 mahasiswa berasal Program Studi Pendidikan Dokter Fakultas Kedokteran dan Ilmu Kesehatan Universitas Warmadewa dan 162 mahasiswa berasal dari Program Studi Pendidikan Dokter Fakultas Kedokteran Universitas Udayana. Sampel dalam penelitian ini memiliki karakteristik (1) Subjek merupakan mahasiswa aktif program studi pendidikan dokter di Kota Denpasar, (2) Subjek sedang mengikuti tahap akademik atau sarjana kedokteran semester I hingga II, (3) Subjek tidak sedang mengulang tahap akademik semester I hingga II, (4) Subjek berusia 18 hingga 25 tahun

Teknik pengambilan sampel yang digunakan dalam penelitian ini adalah teknik simple random sampling yang termasuk salah satu jenis probabaility sampling. Probability sampling merupakan teknik pengambilan sampel yang memberikan peluang yang sama bagi setiap unsur atau anggota populasi untuk dipilih menjadi anggota sampel. Probability sampling berjenis simple random sampling dilakukan secara acak tanpa memperhatikan strata atau tingkatan yang ada di dalam populasi, dengan kata lain anggota populasi dianggap homogen (Sugiyono, 2016). Pengambilan sampel perlu mempertimbangkan ukuran sampel atau jumlah anggota sampel yang digunakan. Penentuan ukuran sampel minimum dari populasi penelitian menggunakan rumus yang dikemukakan oleh Slovin (dikutip dalam Sevilla, Ochave, Punsalan, Regala, \& Uriarte, 1992) sebagai berikut: $\mathrm{n}=\mathrm{N} /\left(1+\mathrm{Ne}^{2}\right)$

Keterangan
n : Ukuran sampel
$\mathrm{N}$ : Ukuran populasi 


\section{$\mathrm{e}^{2}$ : Batas toleransi kesalahan (error of tolerance)}

Berdasarkan rumus tersebut, dengan ukuran populasi sebesar 254 orang, batas toleransi kesalahan sebesar 5\%, maka ukuran sampel minimum dalam penelitian ini adalah sebesar 156 orang atau $61,4 \%$ dari populasi sesungguhnya.

\section{Tempat Penelitian}

Pelaksanaan penelitian dilakukan pada bulan Februari. Pada tanggal 19 Februari 2018 di Fakultas Kedokteran dan Ilmu Kesehatan Universitas Warmadewa, pada tanggal 20 Februari 2018 di Fakultas Kedokteran Universitas Udayana. Jumlah kuesioner yang disebar sebanyak 185 kuesioner, namun jumlah yang kembali dan memenuhi syarat untuk dapat dianalisis sebanyak 158 kuesioner. Melalui penyebaran kuesioner yang dilakukan pada tanggal 19 Februari 2018 dan tanggal 20 Februari 2018, maka jumlah subjek yang digunakan dalam penelitian ini sebanyak 158 orang dan telah memenuhi kriteria ukuran sampel minimum yang telah ditetapkan sebelumnya.

\section{Alat Ukur \\ Alat ukur dalam penelitian ini menggunakan empat skala yaitu Skala Somatic Symptomp Scale - 8 (SSS - 8), Skala Gangguan Psikofisiologis, Skala Stres Akademik, dan Skala Hardiness. Skala Somatic Symptomp Scale - 8 (SSS - 8) diadaptasi dari Gierk et al. (2014) dan diuji cobakan kembali, Skala Gangguan Psikofisiologis disusun berdasarkan pengaruh negatif faktor psikologis terhadap kondisi medis secara umum dari APA (2000) dan Tasman et al. (2009), Skala Stres Akademik disusun berdasarkan reaksi terhadap stres akademik dari Olejnik dan Holschuh (2016), Skala Hardiness disusun berdasarkan trait kepribadian penyusun hardiness serta ciri- ciri individu dengan hardiness dari Kobasa (1982). Skala Somatic Symptomp Scale - 8 (SSS - 8) terdiri dari 8 aitem, Skala Gangguan Psikofisiologis terdiri dari 17 aitem, Skala Stres Akademik terdiri dari 44 aitem, dan Skala Hardiness terdiri dari 32 aitem. Setiap aitem disusun menjadi aitem yang favorable dan unfavorable dengan empat pilihan jawaban yaitu Sangat Sesuai (SS), Sesuai (S), Tidak Sesuai (TS), dan Sangat Tidak Sesuai (STS).}

Sebelum melakukan analisis data, maka dilakukan uji validitas dan uji reliabilitas. Pengujian validitas isi dalam penelitian ini dilakukan dengan menggunakan professional judgment bersama dosen pembimbing, dosen psikologi, dan mahasiswa kedokteran tahun pertama. Pengujian validitas konstrak dilakukan dengan melihat nilai bivariate Pearson correlation, apabila nilai bivariate Pearson correlation atau $r$ hitung lebih besar dari nilai $r$ tabel ( $r$ hitung $>r$ tabel) dan bernilai positif maka aitem dinyatakan valid (Ghozali, 2013). Pengujian reliabilitas dalam penelitian ini menggunakan teknik analisa Cronbach Alpha. Suatu aitem yang memiliki nilai Cronbach Alpha di atas 0,70 telah dikatakan baik dan reliabel (Ghozali, 2013).

Hasil uji validitas Skala Somatic Symptomp Scale - 8 (SSS 8) memiliki nilai bivariate Pearson correlation berkisar pada rentang 0,469 hingga 0,829 . Hasil uji reliabilitas menunjukkan koefisien Alpha $(\alpha)$ sebesar 0,867 , yang berarti Skala Somatic
Symptomp Scale - 8 (SSS - 8) dapat mencerminkan 80,2\% nilai skor murni subjek. Hasil uji validitas Skala Gangguan Psikofisiologis memiliki nilai bivariate Pearson correlation berkisar pada rentang 0,288 hingga 0,806. Hasil uji reliabilitas menunjukkan koefisien Alpha $(\alpha)$ sebesar 0,880, yang berarti bahwa Skala Gangguan Psikofisiologis dapat mencerminkan $88,0 \%$ nilai skor murni subjek. Hasil uji validitas Skala Stres Akademik memiliki nilai bivariate Pearson correlation berkisar pada rentang 0,254 hingga 0,630. Hasil uji reliabilitas menunjukkan Koefisien Alpha $(\alpha)$ sebesar 0,867, yang berarti bahwa Skala Stres Akademik dapat mencerminkan 86,7\% nilai skor murni subjek. Hasil uji validitas Skala Hardiness memiliki nilai bivariate Pearson correlation berkisar pada rentang 0,325 hingga 0,714. Hasil uji reliabilitas menunjukkan Koefisien Alpha $(\alpha)$ sebesar 0,900, yang berarti bahwa Skala Hardiness dapat mencerminkan $90,0 \%$ nilai skor murni subjek.

\section{Teknik Analisis Data}

Uji asumsi dalam penelitian ini menggunakan uji normalitas dengan teknik analisa Kolmogorov-Smirnov (K-S), uji linieritas dengan teknik analisa Test for Linierity, uji multikolinieritas dengan melihat nilai Tolerance dan VIF, dan uji heteroskedastisitas dengan uji Glejser. Uji hipotesis dilakukan dengan menggunakan uji Moderated Regression Analysis (MRA). Uji Moderated Regression Analysis (MRA) digunakan melihat apakah variabel moderator memiliki peran sebagai moderator atau tidak dan memiliki peran memperkuat atau memperlemah hubungan antara variabel bebas terhadap variabel tergantung (Ghozali, 2013).

\section{HASIL PENELITIAN}

\section{Karakteristik Subjek}

Subjek dalam penelitian ini merupakan mahasiswa kedokteran tahun pertama di Kota Denpasa yang berjumlah 158 orang. Apabila dilihat berdasarkan usia, sebagian besar subjek dalam penelitian ini berusia 18 tahun dengan persentase sebesar 63,9\%. Aoabila dilihat berdasarkan jenis kelamin, sebagian besar subjek dalam penelitian ini berjenis kelamin perempuan dengan persentase sebesar $70,3 \%$.

\section{Deskripsi Data Penelitian}

Hasil deskripsi statistik pada tabel 1 (terlampir) menunjukkan bahwa gangguan psikofisiologis memiliki nilai rata-rata teoretis sebesar 42,5 dan nilai rata-rata empiris sebesar 40,85 dan menghasilkan perbedaan sebesar 1,65 dengan nilai $t$ sebesar -2,680 dan signifikansi sebesar 0,000. Nilai rata-rata empiris yang diperoleh lebih kecil dari nilai rata-rata teoretis (nilai rata-rata empiris < nilai rata-rata teoretis) dan nilai signifikansi $\mathrm{t}$ lebih kecil dari 0,005 ( $\mathrm{p}<0.05)$, yang menunjukkan bahwa subjek memiliki kecenderungan gangguan psikofisiologis yang rendah

Hasil deskripsi statistik pada tabel 1 menunjukkan bahwa stres akademik memiliki nilai rata-rata teoretis sebesar 110 dan nilai rata-rata empiris sebesar 102,33 dan menghasilkan perbedaan sebesar 7,67 dengan nlai $t$ sebesar 7,327 dan signifikansi sebesar 0,000 . Nilai rata-rata empiris yang diperoleh lebih kecil dari nilai rata-rata teoretis (nilai rata-rata 
empiris $<$ nilai rata-rata teoretis) dan nilai signifikansi t lebih kecil dari 0,05 $(\mathrm{p}<0,05)$, yang menunjukkan bahwa subjek memiliki taraf stres akademik yang rendah.

Hasil deskripsi statistik pada tabel 1 menunjukkan bahwa hardiness memiliki nilai rata-rata teoretis sebesar 80 dan nilai rata-rata empiris sebesar 96,51 dan menghasilkan perbedaan sebesar 16,51 dengan nilai $\mathrm{t}$ sebsar 20,455 dan signifikansi sebesar 0,000 . Nilai rata-rata empiris yang diperoleh lebih besar dari nilai rata-rata teoretis (nilai rata-rata empiris $>$ nilai rata-rata teoretis) dan nilai signifikansi t lebih kecil dari 0,05 $(\mathrm{p}<0,05)$, yang menunjukkan bahwa subjek memiliki taraf hardiness yang tinggi.

\section{Uji Asumsi}

Uji normalitas dilakukan dengan menggunakan teknik Kolmogorov-Smirnov (K-S). Menurut Ghozali (2013), data disebut berdistribusi normal apabila signifikansi pada Kolmogorov-Smirnov (K-S) lebih besar dari 0,05 ( $\mathrm{p}>0,05)$. Berdasarkan tabel 2 (terlampir), nilai signifikansi variabel gangguan psikofiisiologis sebesar 0,069 ( $>00,05)$, nilai signifikansi variabel stress akademik sebesar $0,106(\mathrm{p}>0,05)$, nilai signifikansi variabel hardiness sebesar $0,067(\mathrm{p}>0,05)$, dan nilai signifikansi residual sebesar $0,859(\mathrm{p}>0,05)$ sehingga dapat dikatakan bahwa data pada ketiga variabel berdistribusi normal.

Uji linearitas dilakukan dengan menggunakan teknik Test for Linearity. Apabila nilai signifikansi lebih kecil daripada 0.05 $(\mathrm{p}<0,05)$ maka hubungan antara kedua variabel penelitian dinyatakan linear (Ghozali, 2013). Berdasarkan tabel 3 (terlampir) variabel stres akademik dan variabel gangguan psikofisiologis sebesar 0,064 ( $p>0,05)$, serta nilai signifkansi pada variabel hardiness dan variabel gangguan psikofisiologis sebesar 0,830 ( $>>0,05)$. Hal ini menunjukkan bahwa data variabel bebas dan variabel moderasi dalam penelitian ini memiliki hubungan yang linear terhadap variabel tegantung.

Uji multikolinieritas dilakukan dengan melihat nilai Tolerance dan VIF. Apabila nilai Tolerance lebih besar sama dengan 0,1 (Tolerance $\geq 0,1$ ) dan nilai VIF lebih kecil sama dengan 10 $(\mathrm{VIF} \leq 10)$, maka dikatakan tidak terjadi multikolinieritas. Berdasarkan tabel 4 (terlampir), diperoleh nilai Tolerance dan VIF pada masing-masing variabel stress akademk dan hardiness sebesar 0,711 dan 1,406. Hal ini menunjukkan tidak ada multikolinearitas antar variabel bebas dalam penelitian ini.

Uji heteroskedastisitas dilakukan menggunakan uji Glejser. Nilai signifikansi harus lebih besar dari $0.05(\mathrm{p}>0,05)$ untuk membuktikan tidak terjadi masalah heteroskedastisitas (Ghozali, 2013). Berdasarkan tabel 5 (terlampir), nilai signifikansi pada variabel stres akademik dan hardiness masing-masing sebesar 0,052 dan 0,697 ( $>>0,05)$. Hal ini menunjukkan tidak terjadi heteroskedastisitas pada model regresi dalam penelitian ini.

\section{Uji Hipotesis}

Uji hipotesis dalam penelitian ini menggunakan teknik Moderated Regression Analysis (MRA) atau regresi dengan variabel moderator dengan teknik uji interaksi. Analisis regresi dengan variabel moderator dipilih sebagai metode analisis data karena dapat menganalisis apakah kehadiran variabel moderator berpengaruh terhadap hubungan yang terjadi antara variabel bebas dan variabel tergantung (Sarwono, 2013).

Berdasarkan tabel 6 (terlampir) diperoleh taraf signifikansi sebesar $0.000 \quad(p<0.05)$. Hal tersebut menunjukkan bahwa variabel stres akademik dan hardiness dapat digunakan untuk memprediksi kecenderungan gangguan psikofisiologis atau stress akademk dan hardiness secara bersama-sama berperan terhadap kecenderungan gangguan psikofisiologis.

Berdasarkan tabel 7 (terlampir) diperoleh nilai $\mathrm{R}$ sebesar 0,649 . Hal ini menunjukkan terdapat hubungan positif antara variabel stress akademik dan hardiness terhadap kecenderungan gangguan paikofisiologis. Berdasarkan tabel 7, diperoleh juga nilai nilai koefisien determinasi sebesar 0,422 , yang menunjukkan bahwa variabel stres akademik dan hardiness berperan sebesar $42,2 \%$ terhadap kecenderungan gangguan psikofisiologis dan variabel lain yang tidak diteliti berperan sebesar 57,8\% terhadap kecenderungan gangguan psikofiisologis.

Berdasarkan tabel 8, stres akademik memiliki nilai koefisien parameter sebesar 0,727 , nilai t sebesar 2,223, dan signifikansi $0,028(\mathrm{p}<0,05)$, sehingga sres akademik berperan secara signifikan terhadap kecenderungan gangguan psikofisiologis. Hardiness memiliki nilai koefisien parameter sebesar 0,443, nilai t sebesar 1,290, dan signifikansi 0,119 ( $\mathrm{p}>0,05)$, sehingga hardiness sebagai variabel prediktor yang mandiri tidak berperan secara signifikan terhadap kecenderungan gangguan psikofisiologis. Moderasi hardiness memiliki nilai koefisien parameter sebesar $-0,003$, nilai $t$ sebesar $-0,942$, dan signifikansi 0,348 ( $>0,05)$, sehingga hardiness sebaagi variabel moderator tidak berperan secara signifikan dalam memperkuat atau memperlemah hubungan antara stres akademik terhadap kecenderungan gangguan psikofisiologis.

Penelitian ini menggunakan satu variabel bebas dan satu variabel moderasi, sehingga rumus persamaan regresi dalam penelitian ini sebagai berikut:

$$
\begin{aligned}
& Y=-46,556+0,727 X 1+0,443 X 2-0,003 X 1 X 2 \\
& \text { Keterangan } \\
& \text { Y : Gangguan psikofisiologis } \\
& \mathrm{X} 1 \quad \text { : Stres akademik } \\
& \mathrm{X} 2 \quad: \text { Hardiness } \\
& \text { X1X2 : Moderasi hardiness (interaksi X1 dan X2) }
\end{aligned}
$$

Persamaan regresi tersebut memiliki arti sebagai berikut:

a. Nilai konstanta sebesar -46,556 menunjukkan bahwa jika variabel stres akademik dan variabel hardiness diasumsikan tetap, maka kecenderungan gangguan psikofisiologis akan menurun sebesar 46,556.

b. Nilai koefisien stres akademik (X1) sebesar 0,727 menunjukkan bahwa setiap terjadi penambahan satuan nilai untuk stres akademik, maka akan diikuti kenaikan nilai sebesar 0,727 satuan. 
c. Nilai koefisien hardiness (X2) sebesar 0,443 menunjukkan bahwa setiap terjadi penambahan satuan nilai untuk hardiness, maka akan diikuti kenaikan nilai sebesar 0,443 satuan.

d. Nilai koefisien moderasi hardiness (X1X2) sebesar -0,003 menunjukkan bahwa setiap terjadi penambahan satuan nilai untuk moderasi hardiness, maka akan diikuti penurunan nilai sebesar 0,003 satuan.

Rangkuman hasil uji hipotesis mayor dan hipotesis minor dalam penelitian ini dapat dilihat pada tabel 9 (terlampir).

\section{PEMBAHASAN DAN KESIMPULAN}

Berdasarkan uji Moderated Regression Analysis (MRA) yang telah dilakukan, diperoleh hasil bahwa stres akademik dan hardiness secara bersama-sama berperan terhadap kecenderungan gangguan psikofisiologis. Variabel stres akademik dan hardiness secara bersama-sama memberikan sumbangan sebesar 42,2\% terhadap kecenderungan gangguan psikofisiologis, sedangkan 57,8\% sisanya merupakan sumbangan dari faktor lain terhadap kecenderungan gangguan psikofisiologis pada mahasiswa kedokteran tahun pertama.

Variabel bebas yang diteliti dalam penelitian ini merupakan stres akademik. Stres akademik merupakan reaksi yang muncul pada peserta didik sebagai hasil kombinasi dari tuntutan akademik yang melebihi sumber daya yang tersedia dalam menghadapi tuntutan akademik (Olejnik \& Holschuh, 2016; Wilks, 2008). Hasil analisis koefisien parameter dari stres akademik menunjukkan bahwa stres akademik memberikan peran positif yang signifikan terhadap kecenderungan gangguan psikofisiologis pada mahasiswa kedokteran tahun pertama, yang berarti, meningkatnya taraf stres akademik akan diikuti dengan meningkatnya kecenderungan gangguan psikofisiologis pada mahasiswa kedokteran tahun pertama. Hasil dari penelitian ini sejalan dengan penelitian yang pernah dilakukan oleh Natvig, Albrektsen, Anderssen, dan Qvarnstrom (2000) dan Murberg dan Bru (2007) yang menunjukkan bahwa terdapat peran yang signifikan antara stres akademik terhadap keluhan somatik dan psikologis, yaitu meningkatnya stres akademik secara konsisten berkaitan dengan meningkatnya risiko bagi peserta didik mengalami gangguan psikofisiologis.

Terdapatnya peran yang signifikan dari stres akademik terhadap kecenderungan gangguan psikologis pada mahasiswa kedokteran tahun pertama dapat disebabkan oleh sistem pendidikan kedokteran. Mahasiswa kedokteran dituntut untuk mempelajari sejumlah besar materi perkuliahan dalam periode yang singkat sebelum akhirnya menjalani ujian dan dievaluasi (Heinen et al., 2017). Selama satu semester, mahasiswa kedokteran akan mengikuti empat hingga lima blok dengan tingkat kesulitan studi dari sistem blok yang semakin meningkat tiap semesternya. Setiap blok umumnya akan diikuti oleh mahasiswa kedokteran dalam jangka waktu satu hingga dua bulan. Sebagai contoh, pada semester pertama, mahasiswa kedokteran akan dihadapkan pada blok I hingga IV. Blok I hingga II terdiri dari Studium Generale and Humaniora dan Biomedik I. Pada blok I hingga II, mahasiswa kedokteran akan mengikuti ujian setiap dua minggu sekali.
Selanjutnya, setelah mengikuti ujian terakhir pada blok I, mahasiswa kedokteran akan melanjutkan ke blok II dan kembali mengikuti ujian seperti yang dilakukan saat berada pada blok I. Menurut Heinen et al. (2017), banyaknya materi perkuliahan yang perlu dipelajari dalam periode yang singkat kemudian menciptakan stres akademik karena ketidakmampuan mahasiswa kedokteran untuk menangani semua informasi sekaligus dan kemungkinan untuk berhasil selama periode ujian menjadi sulit

Gangguan psikofisiologis secara spesifik mengacu pada disfungsi organ atau gejala fisik yang setidaknya dapat disebabkan oleh faktor psikologis seperti stres (Kearney \& Trull, 2012). Berdasarkan model diathesis-stres, sindrom psikofisiologis tertentu terjadi ketika stres berinteraksi dengan sistem tubuh yang rentan (Davison et al., 2014). Stres akademik yang dialami oleh mahasiswa kedokteran tahun pertama menyebabkan banyak perubahan dari segi fisiologis, psikologis, dan sosial yang dapat memengaruhi kondisi kesehatan (Sue et al, 2016). Ketika mahasiswa kedokteran tahun pertama mengalami stres akademik, maka respon fisiologis terhadap stresor akademik seperti hasil ujian yang buruk, banyaknya materi perkuliahan yang harus dipelajari, dan periode mengikuti ujian dapat menyebabkan peningkatan rangsangan berupa peningkatan denyut jantung, tekanan darah, tegangan otot, atau produksi asam lambung (Semiun, 2006). Peningkatan rangsangan yang berlangsung dalam jangka waktu yang lama akan menimbulkan gangguangangguan fisik yang disebut sebagai kecenderungan gangguan psikofisiologis (Semiun, 2006).

Variabel moderator yang diteliti dalam penelitian ini merupakan hardiness. Menurut Kobasa (dikutip dalam Kobasa et al., 1982), hardiness merupakan konstelasi atau sekumpulan trait dari karakteristik kepribadian yang berfungsi sebagai sumber perlawanan ketika menghadapi peristiwa kehidupan yang penuh dengan stres. Berdasarkan konsep yang dikemukakan oleh Kobasa et al. (1982), hardiness dapat berfungsi sebagai moderator dari dampak stres yang membahayakan terhadap kinerja dan kesehatan individu. Berlawanan dari konsep yang dikemukakan oleh Kobasa et al. (1982), hasil koefisien parameter hardiness sebagai variabel moderasi dalam penelitian ini menunjukkan tidak terdapat peran yang signifikan terhadap kecenderungan gangguan psikofisiologis, dengan kata lain, hardiness sebagai variabel moderasi tidak beperan dalam melemahkan hubungan antara stres akademik terhadap kecenderungan gangguan psikofisiologis.

Selanjutnya, berdasarkan perbandingan rata-rata teoretis dan rata-rata empiris data penelitian menunjukkan bahwa taraf hardiness subjek dalam penelitian ini tergolong tinggi. Menurut Kobasa et al. (1982), semakin tinggi hardiness pada individu, maka semakin efektif individu bereaksi terhadap tuntutan yang penuh dengan stres dan semakin sedikit menunjukkan tanda-tanda reaksi stres secara fisiologis. Kendati demikian, berlawanan dengan konsep yang dikemukakan oleh Kobasa et al. (1982), tingginya taraf hardiness subjek pada penelitian ini tidak memiliki peran secara signifikan dalam melemahkan hubungan antara stres 
akademik terhadap kecenderungan gangguan psikofisiologis.

Tidak terdapatnya peran moderasi hardiness yang signifikan dalam penelitian ini dapat dimungkinkan karena proporsi jenis kelamin dan tingkat usia subjek, yaitu sebagian besar subjek yang mengikuti penelitian ini merupakan mahasiswa kedokteran tahun pertama berjenis kelamin perempuan, yaitu sejumlah 111 orang $(70,3 \%)$ dan berusia 18 tahun, yaitu sejumlah 101 orang $(60,9 \%)$.

Pada beberapa penelitian, seperti yang dilakukan oleh Shepperd dan Khasani (1991) dan Klag dan Bradley (2004), ditemukan hasil yang tidak signifikan mengenai peran moderasi hardiness pada subjek berjenis kelamin perempuan. Berdasarkan penelitian yang dilakukan oleh Shepperd dan Khasani (1991), didapat hasil bahwa hardiness tidak berinteraksi dengan stres dalam memprediksi kondisi kesehatan pada subjek berjenis kelamin perempuan. Sejalan dengan hasil penelitian Shepperd dan Khasani (1991), Klag dan Bradley (2004) menyatakan bahwa konsep yang dikemukakan oleh Kobasa et al. (1982) mengenai peran moderasi hardiness terhadap stres dan kondisi kesehatan cenderung sesuai pada subjek berjenis kelamin laki-laki, namun tidak sesuai pada subjek berjenis kelamin perempuan. Menurut Klag dan Bradley (2004), hal ini dapat dimungkinkan karena hardiness mengambil manifestasi yang berbeda pada laki-laki dan perempuan. Misalnya, pada penelitian yang dilakukan oleh Shepperd dan Khasani (1991), didapat hasil bahwa trait komitmen dan kendali memoderasi hubungan antara stres dan kondisi kesehatan cenderung sesuai pada subjek berjenis kelamin laki-laki, namun tidak sesuai pada subjek berjenis kelamin perempuan. Apabila dikaitkan dengan konsep yang dikemukakan oleh Kobasa et al. (1982), trait komitmen dan kendali sejatinya sama-sama memiliki peran sebagai sumber perlawanan ketika mengahadapi peristiwa kehidupan yang penuh dengan stres.

Menurut Kobasa et al. (1982), trait komitmen diungkapkan sebagai kecenderungan untuk melibatkan diri pada apapun yang sedang dilakukan atau dialami oleh individu daripada pengalaman terasing, sedangkan trait kendali diungkapkan sebagai kecenderungan untuk merasakan dan bertindak seolah-olah individu berpengaruh dalam menghadapi berbagai kemungkinan kehidupan daripada ketidakberdayaan. Individu dengan komitmen dalam dirinya akan menghindari perilaku sosial yang tidak produktif ketika berhadapan dengan peristiwa yang penuh dengan stres (Sheard, 2009). Selanjutnya, individu dengan kendali dalam dirinya mengandalkan pusat kendali internal sehingga bertindak seolah-olah dapat memengaruhi kejadian yang terjadi disekitar individu sehingga terhindar dari dampak stres secara negatif (Harrari \& Legge, 2001).

Selain disebabkan oleh proporsi jenis kelamin subjek, tidak terdapatnya peran moderasi hardiness yang signifikan pada penelitian ini dapat dimungkinkan oleh tingkat usia subjek. Pada penelitian yang dilakukan oleh Soderstrom, Dolbier, Leiferman, dan Steinhardt (2000), didapat hasil bahwa peran moderasi hardiness terhadap gejala penyakit cenderung sesuai pada subjek yang berasal dari kalangan pekerja, namun cenderung tidak sesuai pada subjek yang berasal dari kalangan mahasiswa. Kesenjangan ini dapat dimungkinkan oleh perbedaan usia antara subjek yang berasal dari kalangan pekerja yang berusia rata-rata 42 tahun dan subjek yang berasal dari kalangan mahasiswa yang berusia rata-rata 19 tahun (Soderstrom et al., 2000). Hal ini dapat dikaitkan dengan konsep yang dikemukakan oleh Kobasa et al. (1982) bahwa semakin banyak pengalaman hidup yang dimiliki oleh seseorang, maka semakin kuat diri seseorang. Selanjutnya, semakin jelas hardiness dalam diri seseorang, maka akan semakin berperan secara langsung terhadap kondisi kesehatan individu.

Berdasarkan kesimpulan yang telah dipaparkan, maka peneliti dapat memberikan saran bagi mahasiswa kedokteran tahun pertama hendaknya tidak mengabaikan kondisi stres akademik yang dialami selama mengikuti pendidikan kedokteran, karena stres akademik yang dialami oleh mahasiswa kedokteran tahun pertama dapat mengarah pada munculnya kecenderungan gangguan psikofisiologis. Mahasiswa kedokteran tahun pertama juga hendaknya mampu melakukan perawatan psikologis berupa relaksasi atau manajemen stres akademik secara mandiri, sehingga stres akademik yang dialami selama masa studi tidak mengarah pada munculnya kecenderungan gangguan psikofisiologis.

Saran bagi institusi pendidikan kedokteran, yaitu hendaknya melakukan evaluasi bersama perwakilan mahasiswa selama periode waktu tertentu mengenai sistem pendidikan kedokteran, sehingga hasilnya dapat menjadi masukan bagi institusi pendidikan kedokteran untuk peningkatan mutu dan kualitas pendidikan kedokteran. Institusi pendidikan kedokteran juga hendaknya dapat mengadakan pelatihan atau pendampingan perawatan psikologis seperti pelatihan relaksasi, manajemen stres akademik, maupun penyediaan layanan konseling pada mahasiswa kedokteran tahun pertama, sehingga dapat mengantisipasi munculnya kecenderungan gangguan psikofisiologis pada mahasiswa kedokteran tahun pertama selama masa studi.

Ruang lingkup gangguan psikofisiologis dalam penelitian ini mencakup beberapa gangguan fisik yang dipengaruhi secara negatif oleh faktor psikologis, yaitu stres akademik, sehingga saran bagi penelitian selanjutnya yang tertarik untuk meneliti topik gangguan psikofisiologis, hendaknya memfokuskan pada satu jenis gangguan fisik dengan tetap mengacu pada konsep teoretis dan hasil-hasil penelitian terdahulu. Penelitian selanjutnya yang tertarik untuk meneliti topik stres akademik, hendaknya mempertimbangkan waktu pengambilan data penelitian, sehingga memperoleh hasil pengukuran taraf stres akademik yang lebih akurat atau benar-benar merepresentasikan taraf stres akademik subjek penelitian. Tidak terdapatnya peran moderasi hardiness secara signifikan terhadap hubungan stres akademik dan kecenderungan gangguan psikofisiogis pada penelitian ini dapat dimungkinkan karena proporsi jenis kelamin dan tingkat usia subjek, sehingga penelitian selanjutnya yang tertarik untuk meneliti topik serupa, terutama hardiness, hendaknya mempertimbangkan komposisi subjek yang akan diteliti dengan tetap mengacu pada konsep teoretis dan hasil-hasil 
penelitian terdahulu.

\section{DAFTAR PUSTAKA}

Abdulghani, H. M., AlKanhal, A. A., Mahmoud, E. S., Ponnamperuma, G. G., \& Alfaris, E. A. (2011). Stress and its effects on medical students: A cross-sectional study at a college of medicine in Saudi Arabia. Journal of Health, Population and Nutrition, 29, 516-522. doi:10.3329/jhpn.v29i5.8906.

American Psychiatric Association. (2000). Diagnostic and statistical manual of mental disorders (4th Rev ed.). Washington, DC: Author.

American Psychiatric Association. (2013). Diagnostic and statistical manual of mental disorders (5th ed.). Washington, DC: Author.

Atkinson, L. R., Atkinson, C. R., \& Hilgard, R. E. (1999). Pengantar psikologi (Jilid 2, edisi ke-8). Jakarta: Erlangga.

Azwar, S. (2016a). Reliabilitas dan validitas (Edisi 4). Yogyakarta: Pustaka Pelajar.

Azwar, S. (2016b). Tes prestasi: Fungsi dan pengembangan pengukuran prestasi belajar (Edisi 2). Yogyakarta: Pustaka Pelajar.

Azwar, S. (2016c). Penyusunan skala psikologi (Edisi 2). Yogyakarta: Pustaka Pelajar.

Augesti, G. (2015). Perbedaan tingkat stres antara mahasiswa tingkat awal dan tingkat akhir Fakultas Kedokteran Universitas Lampung (Skripsi, Universitas Lampung). Retrieved from http://digilib.unila.ac.id/7018/

Bullington, J. (2013). The expression of the psychosomatic body from a phenomenological perspective. Springer Science \& Business Media.

Cacioppo, J., Tassinary, L. G., \& Berntson, G. G. (2007). The handbook of psychophysiology, (3rd ed.). New York: Cambridge University Pers

Chinawa, J. M., Nwokocha, A. R. C., Manyike, P. C., Chinawa, A. T., Aniwada, E. C. \& Ndukuba, A. C. (2016). Psychosomatic problems among medical students: A myth or reality? International Journal of Mental Health Systems, 10, 1-5. doi: 10.1186/s13033-016-0105-3.

Chincholikar, S. V., \& Kulkarini. (2017). An insight into hardiness status of medical undergraduates. Indian Journal of Community Health, 29(2), 191-193. Diakses dari http://www.iapsmupuk.org/journal/index.php/IJCH/article/ view/1703

Christyanti, D., Mustami'ah, D., \& Sulistiani, W. (2010). Hubungan antara penyesuaian diri terhadap tuntutan akademik dengan kecenderungan stres pada mahasiswa Fakultas Kedokteran Universitas Hang Tuah Surabaya. INSAN, 12(3), 153-159. Diakses http://dspace.hangtuah.ac.id/xmlui/handle/dx/585

Davison, G. C., Neale, J. M., \& Kring, A. M. (2014). Psikologi abnormal (Edisi ke-9). Jakarta: Rajagrafindo Persada.

Feist, J., \& Feist, G. J. (2013). Teori kepribadian (Edisi 7). Jakarta: Selemba Humanika.

Field, A. (2009). Discovering statistics using SPSS. London: SAGE Publications.

Gellman, M. D., \& Turner, J. R. (2012). Encyclopedia of behavioral medicine. New York: Springer.

Ghozali, I. (2013). Aplikasi analisis multivariate dengan program IBM SPSS 23 (Edisi 8). Semarang: Badan Penerbit Universitas Diponegoro.

Gierk, B., Kohlamann, S., Kroenke, K., Spangenberg, L., Zenger, M, Brahler, E., \& Lowe, B. (2014). The Somatic Symptom Scale-8 (SSS-8). JAMA Intern Med, 174, 399-407. doi:10.1001/jamainternmed.2013.12179
Gunawan, A. W. (2012). The miracle of mind body medicine. Jakarta: Gramedia Pustaka Utama.

Harari, P. \& Legge, K. (2001). Heinemann themes in psychology: Psychology and health. London: Heinemann Educational.

Heiman, T., \& Kariv, D. (2005). Task-oriented versus emotionoriented coping strategies: The case of college students. College Students Journal, 39(1), 72-89. Diakses dari https://eric.ed.gov/?id=EJ711897

Heinen, I, Bullinger, M., \& Kocalevent, R. (2017). Perceived stress in first year medical students - associations with personal resources and emotional distress. BMC Medical Education, 17, 1-14. doi:10.1186/s12909-016-0841-8.

Himpunan Mahasiswa Kedokteran Umum Fakultas Kedokteran Universitas Udayana. (2014, 8 Maret). Proses belajar prodi kedokteran umum. Diakses 23 September, 2017, dari http://hmku.fkunud.com/proses-belajar-prodi-kedokteranumum/

Hystad, W. S., Eid, J., Laberg, J. C., Johnsen, B. H., \& Bartone, P. T. (2009). Academic stress and health: Exploring the moderating role of personality hardiness. Scandinavian Journal of Educational Research, 53, 421-429. doi:10.1080/00313830903180349.

Kamtsios, S. \& Karagiannopoulou. E. (2015). Exploring relationships between academic hardiness, academic stressors and achievement in university undergraduates. Journal of Applied Educational and Policy Research, 1(1), 53-73. Diakses https://journals.uncc.edu/jaepr/article/view/317

Kaplan, H. I., Sadock, B. J., \& Grebb, J. A. (2010). Sinopsis psikiatri (Jilid 2). Tangerang: Binarupa Aksara.

Kearney, C. A., \& Trull, T. J. (2012). Abnormal psychology and life A dimensional approach. USA: Wadsworth.

Khan, M. J., Altaf, S., \& Kausar, H. (2013). Effect of perceived academic stress on students' performance. FWU Journal of Social Sciences, 7(2), 146-151. Diakses dari http://sbbwu.edu.pk/journal/pages/FWUJournalVol.7,No.2. $\mathrm{php}$

King, L. A. (2014). Psikologi umum: Sebuah pandangan apresiatif (Buku 2). Jakarta: Salemba Humanika

Kobasa, S. C. (1979). Stressful life events, personality, and health: An inquiry into hardiness. Journal of personality and Social Psychology, 37, 1-11. doi:10.1037/0022-3514.37.1.1

Kobasa, S. C., Maddi, S. R., \& Khan, S. (1982). Hardiness and health: A prospective study. Journal of Personality and Social Psychology, 42, 168-177. doi:10.1037/00223514.42.1.168

Klag, S., \& Bradley, G. (2004). The role of hardiness in stress and illness: An exploration of the effect of negative affectivity and gender. British Journal of Health Psychology, 9, 136161. doi:10.1348/135910704773891014

Konsil Kedokteran Indonesia. (2012). Standar pendidikan profesi dokter. Jakarta: Konsil Kedokteran Indonesia.

Lin, Y. M. \& Chen, F. S. (2009). Academic stress inventory of students at universities and colleges of technology. World Transactions on Engineering and Technology Education, 7(2), 157-162. Diakses dari http://www.wiete.com.au/journals/WTE\&TE/Pages/TOC V7N2.html

Lickerman, A. (2010, 4 Maret). Psychosomatic symptoms Psychology Today. Diakses 25 Februari, 2017, dari https://www.psychologytoday.com/blog/happiness-inworld/201003/ psychosomatic-symptoms

Maddi, S. R. (2013). Hardiness: Turning stressful circumstances into resilient growth. Dordrecht: Springer.

Maulana, Z. F., Soleha, T. U., Saftarina, F., \& Siagian, J. M. C. (2014). Perbedaan tingkat stres antara mahasiswa tahun pertama dan tahun kedua di Fakultas Kedokteran 
Universitas Lampung. Medical Journal of Lampung University, 3(4), 154-162. Diakses dari http://juke.kedokteran.unila.ac.id/index.php/majority/article /view/255

Murberg, T. A. \& Bru, E. (2007). School-related stress and psychosomatic symptoms among adolescents. School Psychology International, 25, 317-332. doi: $10.1177 / 0143034304046904$

Navas, S. (2012). Stress among medical students. Kerala Medical Journal, 5(2), 34-37. Diakses dari http://journals.publishmed.com/index.php/KMJ/article/view $1303 / 320$

Natvig, G. K., Albrektsen, G., Anderssen, N., \& Qvarnstrom, U. (2000). Academic stress and psychosomatic symptomp among adolescents. Journal of School Health, 69, 362-368. doi:10.1111/j.1746-1561.1999.tb06430.x

Nguyen, T. D., Shultz, C. J., \& Westbrook, M. D. (2012). Psychological hardiness in learning and quality of college life of business students: Evidence from Vietnam. Journal of Happiness Studies, 13, 1091-1103. doi:10.1007/s10902011-9308-0

Nurtjahjanti, H. \& Ratnaningsih, I. Z. (2011). Hubungan kepribadian hardiness dengan optimisme pada Calon Tenaga Kerja Indonesia (CTKI) wanita di BLKLN Disnakertrans Jawa Tengah. Jurnal Psikologi Undip, 10, 126-132. doi:10.14710/jpu.10.2.126-132

Olejnik, S. N. \& Holschuh, J. P. (2016). College rules! 4th edition: How to study, survive, and succeed. New York: Ten Speed Press.

Peraturan Pemerintah Republik Indonesia Nomor 30 Tahun 1990 tentang Pendidikan Tinggi.

Pramudiarja, A. U. (2011, 5 Mei). 30 persen pasien dokter umum sebenarnya hanya stres. Detik Health. Diakses 26 Februari, 2017, dari http://health.detik.com/read/2011/05/05/ 150459/1633291/763/30-persen-pasien-dokter-umumsebenarnya-hanya-stres

Pratiwi, D. \& Lailatushifah, S. N. F. (2007). Kematangan emosi dan psikosomatis pada mahasiswa tingkat akhir. Insight, Jurnal Ilmiah Psikologi. Diakses dari http://fpsi.mercubuanayogya.ac.id/jurnal-ilmiah/

Santrock, J. W. (2007). Remaja. Jakarta: Erlangga

Santrock, J. W. (2011). Life-span development (13th ed.). New York, NY: McGraw-Hill.

Sarafino, E. P., \& Smith, T. W. (2010). Health psychology: Biopsychosocial interactions (7th ed.). Hoboken, NJ: John Wiley \& Sons Inc.

Sarwono, J. (2013). Statistik multivariat aplikasi untuk riset skripsi. Yogyakarta: Andi Offset.

Semiun, Y. (2006). Kesehatan mental (Edisi 2). Yogyakarta: Kanisius.

Sevilla, C. G., Ochave, J. A., Punsalan, T. G., Regala, B. P., Uriarte, G. G. (1992). Research method. Philippines: Rex Book Store

Sheard, M. (2009). Hardiness commitment, gender, and age differentiate university academic performance. British Journal of Educational Psychology, 79, 189-204. doi: 10.1348/000709908X304406

Shepperd, J. A., \& Kashani, J. H. (1991). The relationship of hardiness, gender, and stress to health outcomes in adolescent. Journal of Personality 59, 747-768. doi: 10.1111/j.1467-6494.1991.tb00930.x

Shriatnia, K., Mirdoraghi, F., Pakmehr, H., \& Iravani, M. R. (2013). A study of relationship between hardiness and self-efficacy with mental health in Iran. Journal of Basic and Applied Scientific Research, 3(7), 760-764. Diakses dari
https://www.semanticscholar.org/paper/A-Study-ofRelationship-between-Hardines

s-and-Self-Shriatnia-

Mirdoraghi/e0acfcdb98448b4957666bf4851eb0f256a85f64

Soderstrom, M., Dolbier, C., Leiferman, J., \& Steinhardt, M. (2000). The relationship of hardiness, coping strategies, and perceived stress to symptoms of illness. Journal of Behavioral Medicine, 23, 311-328. doi: 10.1023/A:1005514310142

Sue, D., Sue, D. W., Sue, D. M., \& Sue, S. (2016). Understanding abnormal behavior (11th ed.). Stamford, CT: Cengange Learning

Sugiyono. (2012). Metode penelitian bisnis. Bandung: Alfabeta.

Sugiyono. (2016). Metode penelitian kuantitatif, kualitatif, dan kombinasi (mixed methods). Bandung: Alfabeta

Sutjiato, M., Kandou, G. D. \& Tucunan, A. A. T. (2015). Hubungan faktor internal dan eksternal dengan tingkat stress pada mahasiswa Fakultas Kedokteran Universitas Sam Ratulangi Manado. JIKMU, 5(1). 30-42. Diakses dari https://ejournal.unsrat.ac.id/index.php/jikmu/article/view/71 76

Tamaya, F. R. (2016). Hubungan antara hardiness dengan academic stress pada mahasiswa strata satu Universitas Syiah Kuala (Skripsi, Universitas Syah Kuala). Diakses dari http://etd.unsyiah.ac.id/index.php?p=show_detail\&id=2396 5

Tasman, A., Kay, J., Lieberman, J. A., First, M. B., \& Maj, M (2008). Psychiatry (3rd ed.). England: John Wiley \& Sons.

Taylor, S. E., Peplau, L. A., \& Sears, D. O. (2009). Psikologi sosial edisi kedua belas. Jakarta: Kencana.

Taylor, S. E. (2012). Health psychology (9th ed.). New York: McGraw-Hill Education.

Undang-Undang Republik Indonesia Nomor 20 Tahun 2013 tentang Pendidikan Kedokteran

Universitas Udayana (2010). Peraturan akademik Universitas Udayana. Bukit Jimbaran: Universitas Udayana.

Universitas Udayana (2016). Peraturan akademik Program Studi Pendidikan Dokter Universitas Udayana. Bukit Jimbaran: Universitas Udayana

Van Hasselt, V. B., \& Hersen, M. (1994). Advanced abnorma psychology. New York: Plenum Press.

Widiastuti, D. Z., \& Astuti, K. (2008). Hubungan antara hardiness dengan burnout pada guru sekolah dasar. Insight, Jurnal Ilmiah Psikologi. Diakses dari http://fpsi.mercubuanayogya.ac.id/jurnal-ilmiah/

Wilks (2008). Resilience amid academic stress: The moderating impact of social support among social work students. Advances in Social Work, 9(2), 106-125. Diakses dari http://journals.iupui.edu/index.php/advancesinsocialwork/ar ticle/view/51

Yumba, W. (2010). Academic stress: A case of the undergraduate students. (Dissertation, Linköping University). Diakses dari http://www.divaportal.org/smash/record.jsf?pid=diva2\%3A556335\&dswid $\underline{=2653}$ 


\section{LAMPIRAN}

Tabel 1

Deskripsi statistik data penelitian

\begin{tabular}{cccc}
\hline Deskripsi Data & $\begin{array}{c}\text { Gangguan } \\
\text { Psikofisiologis }\end{array}$ & Stres Akademik & Hardiness \\
\hline N & 158 & 158 & 158 \\
Rata-rata Teoretis & 42.5 & 110 & 11280 \\
Rata-rata Empiris & 40.85 & 102.33 & 96.51 \\
Std. Deviasi Teoretis & 8.5 & 22 & 16 \\
Std. Deviasi Empiris & 7.717 & 13.160 & 10.147 \\
Xmin & 18 & 47 & 69 \\
Xmax & 58 & 134 & 123 \\
Sebaran Teoretis & $17-68$ & $44-176$ & $32-128$ \\
Sebaran Empiris & $18-58$ & $47-134$ & $69-123$ \\
t & -2.680 & -7.327 & 20.455 \\
& $($ Sig $=0,000)$ & $($ Sig $=0,000)$ & $($ Sig $=0,000)$ \\
\hline
\end{tabular}

Tabel 2

Hasil uji normalitas data penelitian

\begin{tabular}{cccc}
\hline Variabel & $\begin{array}{c}\text { Kolmogorov- } \\
\text { Smirnov }\end{array}$ & $\mathrm{p}$ & Keterangan \\
\hline Gangguan Psikofisiologis & 1.297 & 0.069 & Data berdistribusi nomal \\
Stres Akademik & 1.211 & 0.106 & Data berdistribusi nomal \\
Hardiness & 1.304 & 0.067 & Data berdistribusi nomal \\
Residual & 0.604 & 0.859 & Data berdistribusi nomal
\end{tabular}

Tabel 3

Hasil uji linearitas data penelitian

\begin{tabular}{ccc}
\hline Variabel & Sig. & Keterangan \\
\hline Stres Akademik*Gangguan Psikofisiologis & 0.064 & Data berhubungan secara linear \\
Hardiness*Gangguan Psikofisiologis & 0.830 & Data berhubungan secara linear \\
\hline
\end{tabular}

Tabel 4

Hasil uji multikolenieritas data penelitian

\begin{tabular}{cccr}
\hline Variabel & Tolerance & $\begin{array}{c}\text { Variance Inflation } \\
\text { Factor (VIF) }\end{array}$ & Keterangan \\
\hline $\begin{array}{c}\text { Stres Akademik } \\
\text { Hardiness }\end{array}$ & 0.711 & 1.406 & Tidak terjadi multikolinieritas \\
\hline $\mathbf{r}$ & 0.711 & 1.406 & Tidak terjadi multikolinieritas \\
\hline
\end{tabular}


Tabel 5

Hasil uji heterokeditisititas data penelitian

\begin{tabular}{cccccc}
\hline Model & \multicolumn{2}{c}{ Unstandardized Coefficients } & $\begin{array}{c}\text { Standardized } \\
\text { Coefficients }\end{array}$ & $\mathrm{t}$ & Sig. \\
\hline \multicolumn{7}{c}{$\mathrm{B}$} & Std. Error & Beta & & \\
\hline (Constant) & 10.779 & 4.799 & & 2.250 & 0.026 \\
Stres Akademik & -0.047 & 0.024 & -0.184 & -1.960 & 0.052 \\
Hardiness & -0.012 & 0.031 & -0.037 & -0.390 & 0.697 \\
\hline
\end{tabular}

Tabel 6

Hasil uji signifikan simultan moderated regression analysis ( $m r a)$

\begin{tabular}{ccccccc}
\hline & & Sum of Squares & $d f$ & Mean Square & F & Sig. \\
\hline \multirow{4}{*}{1} & Regression & 3941.130 & 3 & 1313.710 & 37.460 & .000 \\
& Residual & 5408.552 & 154 & 35.120 & & \\
& Total & 9349.652 & 157 & & & \\
\hline
\end{tabular}

Tabel 7

Besaran sumbangan efektif stres akademik dan hardiness terhadap kecenderungan gangguan psikofisiologis

\begin{tabular}{ccccc}
\hline Model & $R$ & $R$ Square & Adjusted R Square & Std. Error of the Estimate \\
\hline 1 & 0,649 & 0,422 & 0,410 & 5.926 \\
\hline
\end{tabular}

Tabel 8

Hasil uji signifikansi parameter individual moderated regression analysis (mra)

\begin{tabular}{ccccccc}
\hline & Model & \multicolumn{2}{c}{ Unstardardized Coefficients } & $\begin{array}{c}\text { Standardized } \\
\text { Coefficients }\end{array}$ & \multirow{2}{*}{$\mathrm{t}$} & \multirow{2}{*}{ Sig. } \\
\cline { 3 - 5 } & \multicolumn{2}{c}{$\mathrm{B}$} & Std. Error & Beta & & \\
\cline { 3 - 6 } 1 & (Constant) & -46.556 & 35.326 & & -1.318 & 0,189 \\
& Stres Akademik & 0.727 & 0.327 & 1.240 & 2.223 & 0,028 \\
& Hardiness & 0.443 & 0.343 & 0.583 & 1.290 & 0,119 \\
& Moderasi & -0.003 & 0.003 & -0.465 & -0.942 & 0.348 \\
\hline
\end{tabular}


Tabel 9

Rangkuman hasil uji hipotesis penelitian

\begin{tabular}{|c|c|c|}
\hline $\begin{array}{l}\mathrm{N} \\
\mathrm{o}\end{array}$ & Hipotesis & Hasil \\
\hline 1. & $\begin{array}{l}\text { Hipotesis Mayor: } \\
\text { Terdapat peran antara stres akademik dan hardiness terhadap } \\
\text { kecenderungan gangguan psikofisiologis. }\end{array}$ & $\begin{array}{l}\mathrm{H}_{\mathrm{a}} \\
\text { Diterim } \\
\mathrm{a}\end{array}$ \\
\hline 2. & $\begin{array}{l}\text { Hipotesis Minor I } \\
\text { Terdapat peran stres akademik terhadap kecenderungan gangguan } \\
\text { psikofisiologis. }\end{array}$ & $\begin{array}{l}\mathrm{H}_{\mathrm{a}} \\
\text { Diterim } \\
\mathrm{a}\end{array}$ \\
\hline & $\begin{array}{l}\text { Hipotesis Minor II } \\
\text { Terdapat peran moderasi hardiness terhadap hubungan stres akademik } \\
\text { terhadap kecenderungan gangguan psikofisiologis. }\end{array}$ & $\begin{array}{l}\mathrm{H}_{0} \\
\text { Diterim } \\
\mathrm{a}\end{array}$ \\
\hline
\end{tabular}

